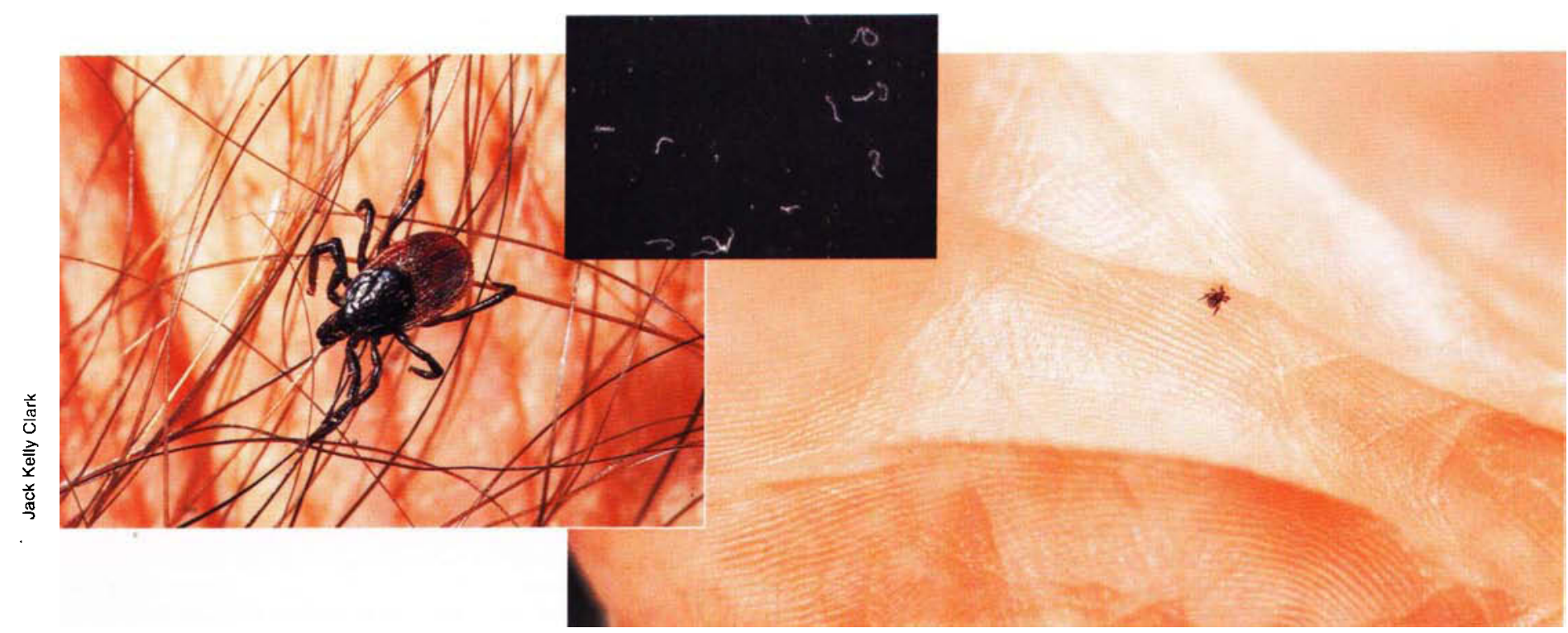

The western black-legged tick adult female, left, and nymph, right, can carry the spirochete, middle, that causes Lyme disease. At about 1/20 of an inch long, the nymph can be dangerously inconspicuous. In areas of Northern California where Lyme disease is prevalent, about $5 \%$ to $15 \%$ of nymphs may be infected with the spirochete.

\title{
Research on animal-borne parasites and pathogens helps prevent human disease
}

Robert S. Lane 」 John R. Anderson

\author{
A large body of basic and \\ applied research conducted at \\ the UC Hopland Research and \\ Extension Center (HREC) has \\ focused on micro- or \\ macroparasites that infest \\ humans, domestic animals and \\ wildlife, including viruses, \\ bacteria, protozoans, helminths \\ and blood-sucking arthropods. \\ Approximately 17 micro- \\ organisms detected at the \\ HREC are transmitted by ticks, \\ and of these, at least five cause \\ zoonotic diseases - animal- \\ borne diseases that can be \\ transmitted to people. \\ Scientists working at the HREC \\ identified the basic trans- \\ mission cycle of the Lyme \\ disease spirochete in the far- \\ western United States. This \\ information now is being used \\ to develop and implement risk- \\ assessment and preventive \\ strategies.
}

\author{
The past quarter-century has wit- \\ nessed a tremendous rebirth of in- \\ terest in infectious diseases, in part \\ because of the emergence or resur- \\ gence of various arthropod-borne dis- \\ eases in the tropics and temperate re- \\ gions (Gubler 1998; Gratz 1999). \\ According to the U.S. Centers for Dis- \\ ease Control and Prevention (CDC \\ 1994), emerging diseases are those in- \\ fectious diseases whose incidence in \\ humans has either increased within \\ the past 20 years or is likely to increase \\ in the near future. In the Northern \\ Hemisphere, tick-borne diseases that \\ have emerged as public health threats \\ include Lyme disease, human \\ ehrlichiosis and human babesiosis. \\ Lyme disease alone accounts for over \\ $95 \%$ of the reported human cases of ar- \\ thropod-borne diseases in the United \\ States (CDC 1999) and in some years, a \\ comparable portion of such cases in \\ California. \\ In the mid-1970s, when Lyme dis- \\ ease was first recognized in the United \\ States, an ecologic and epidemiologic \\ research program on human tick- \\ borne diseases was initiated at the
}

HREC. This paper discusses some of the novel parasitologic findings emanating from investigations of macroparasites of deer, and of Lyme disease and other tick-borne diseases hosted by wildlife, and how this information is being used to develop and implement risk-assessment and preventive strategies.

\section{Zoonotic diseases}

Zoonoses are infectious diseases whose agents can be transmitted between nonhuman vertebrates and people. Of the 1,709 infectious organisms known to cause diseases in humans, $49 \%$ are zoonotic as are $73 \%$ of the 156 pathogens that are considered emerging (Taylor and Woolhouse 2000). Furthermore, $89 \%$ of the 374 species of parasites known to infest humans are zoonotic in origin (Morgan 2000).

Zoonoses can be transmitted to humans by direct contact with either an infectious vertebrate host or an inanimate object harboring a disease agent; by ingestion of contaminated water, food or other organic matter; by inha- 
lation; and by arthropod vectors (Lane in press). Many zoonotic agents are transmitted to humans by bloodsucking arthropods, particularly insects and ticks. In fact, two of the three internationally quarantinable contemporary diseases are arthropod-borne zoonoses transmitted by either mosquitoes (yellow fever) or fleas (plague). In the tropics and subtropics, the most significant arthropod-borne zoonotic disease agents are conveyed by flies (such as malaria, African trypanosomiasis), whereas in temperate regions they are primarily tick-borne (such as Lyme disease, ehrlichiosis).

Although tick-transmitted diseases predominate in temperate climates, mosquito-borne zoonoses cause local or regional outbreaks from time to time that seriously endanger the public health. In the summer of 1999, an unprecedented epidemic of the exotic West Nile virus occurred in the northeastern United States, which was the first time this mosquito-borne arbovirus had been detected in the Western Hemisphere. According to the CDC, more than 800 suspected human cases were identified by active surveillance in New York state; of these, 62 were laboratory-confirmed, and seven people died. Horses and exotic and native birds also were infected with the virus, and certain species, especially the American crow, suffered considerable mortality. Since then, the geographic distribution of West Nile virus has expanded rapidly in the eastern United States.

\section{Infectious diseases of wildlife}

Many factors can contribute to the emergence or re-emergence of arthropod-borne diseases, including a breakdown in public health infrastructures or demographic changes. However, these diseases often occur as a direct result of ecological changes in hosts, pathogens and vector populations (CDC 1994; Gubler 1998; Gratz 1999; Daszak et al. 2000). A shared element among emerging or re-emerging vector-borne diseases is that typically they result from environmental changes that favor an increased abundance of vector arthropods (Gratz

TABLE 1. Tick-borne pathogens detected in or isolated from ticks, vertebrates or both at HREC

\begin{tabular}{|c|c|c|c|c|c|}
\hline $\begin{array}{l}\text { Agent } \\
\text { (disease) }\end{array}$ & $\begin{array}{l}\text { Primary tick } \\
\text { vectors }\end{array}$ & $\begin{array}{c}\text { Primary } \\
\text { vertebrate hosts }\end{array}$ & $\begin{array}{l}\text { Pathoger } \\
\text { Humans }\end{array}$ & $\begin{array}{l}\text { Domestic } \\
\text { Dor } \\
\text { animals }\end{array}$ & Key references \\
\hline \multicolumn{6}{|l|}{ Virus } \\
\hline $\begin{array}{l}\text { Coltivirus } \\
\text { (Colorado tick } \\
\text { fever-like) }\end{array}$ & Unknown & $\begin{array}{l}\text { Black-tailed } \\
\text { jackrabbit }\end{array}$ & $?^{*}$ & ? & Lane et al. (1982) \\
\hline \multicolumn{6}{|l|}{ Rickettsiae } \\
\hline $\begin{array}{l}\text { Anaplasma marginale } \\
\text { (anaplasmosis) }\end{array}$ & $\begin{array}{l}\text { Dermacentor } \\
\text { occidentalis }\end{array}$ & Cattle, deer & & + & $\begin{array}{l}\text { Howarth and } \\
\text { Hokama (1973); } \\
\text { Howarth and } \\
\text { Roby (1973) }\end{array}$ \\
\hline $\begin{array}{l}\text { Coxiella burnetii } \\
\text { (Q-fever) }\end{array}$ & $\begin{array}{l}\text { D. occidentalis, } \\
\text { Ornithodoros } \\
\text { coriaceus }\end{array}$ & $\begin{array}{l}\text { Sheep, other species } \\
\text { of wildlife (including } \\
\text { birds and mammals) }\end{array}$ & + & + & $\begin{array}{l}\text { Enright et al. } \\
\text { (see below§) }\end{array}$ \\
\hline $\begin{array}{l}\text { Rickettsia rickettsii } \\
\text { (Rocky Mountain } \\
\text { spotted fever) }\end{array}$ & D. occidentalis & $\begin{array}{l}\text { Rodents, } \\
\text { lagomorphs } †\end{array}$ & + & + & $\begin{array}{l}\text { Lane et al. } \\
\text { (1981a, 1981b); } \\
\text { Philip et al. } \\
\text { (1981) }\end{array}$ \\
\hline \multicolumn{6}{|l|}{ Other bacteria } \\
\hline $\begin{array}{l}\text { Borrelia bissettii } \\
\text { (Lyme disease-like) }\end{array}$ & $\begin{array}{l}\text { Ixodes } \\
\text { spinipalpis }\end{array}$ & Rodents & $+\ddagger$ & & $\begin{array}{l}\text { Postic et al. } \\
\text { (1998) }\end{array}$ \\
\hline $\begin{array}{l}\text { B. burgdorferi } \\
\text { (Lyme disease) }\end{array}$ & I. pacificus & Rodents & + & + & $\begin{array}{l}\text { Burgdorfer et al. } \\
(1985) ; \text { Brown } \\
\text { and Lane (1992) }\end{array}$ \\
\hline $\begin{array}{l}\text { B. coriaceae } \\
\text { (epizootic bovine } \\
\text { abortion?) }\end{array}$ & O. coriaceus & Deer & & $?$ & $\begin{array}{l}\text { Lane et al. } \\
(1985) ; \\
\text { Johnson et al. } \\
(1987)\end{array}$ \\
\hline $\begin{array}{l}\text { Francisella tularensis } \\
\text { (tularemia) }\end{array}$ & D. occidentalis & $\begin{array}{l}\text { Rodents, } \\
\text { lagomorphs }\end{array}$ & + & + & $\begin{array}{l}\text { Lane and } \\
\text { Emmons (1977) }\end{array}$ \\
\hline
\end{tabular}

1999). In the northeastern United

States, deforestation and urbanization resulted in population increases in wildlife (such as deer) and their associated ticks around the home environment, which enhanced transmission of the agent of Lyme disease to people.

In addition to hosting zoonotic agents, wildlife can also serve as reservoirs of infectious disease organisms that affect livestock or companion animals, such as anaplasmosis, plague and Q-fever. Moreover, wildlife can contract emerging infectious diseases as a result of spillover from domestic animals or human intervention (Daszak et al. 2000). Such spillover has been well documented at the HREC, where 28 species of parasitic worms infest sheep and deer alike, and several important gastrointestinal nematodes are transmitted between these ungulates in both directions (Longhurst and Douglas 1953; Baker et al. 1954; Baker et al. 1957). Transfer- ence of parasites can be especially menacing to susceptible endangered species because it may lead to local extinction of populations (Daszak et al. 2000). Thus, the endangered African wild dog is vulnerable to canine distemper and rabies viruses that may be contracted from domestic dog carriers.

People can introduce exotic pathogens into native wildlife by translocating nonindigenous wildlife for hunting, agriculture and conservation. Furthermore, mounting evidence suggests that wild primates in frequent contact with scientists and ecotourists are contracting human diseases at an alarming rate in Africa (Ferber 2000). For example, wild mountain gorillas are threatened by measles acquired directly from humans (Daszak et al. 2000). Wildlife also can experience emerging infectious diseases due to changeable weather patterns (such as the El Niño Southern Oscillation), which can promote increases in the 

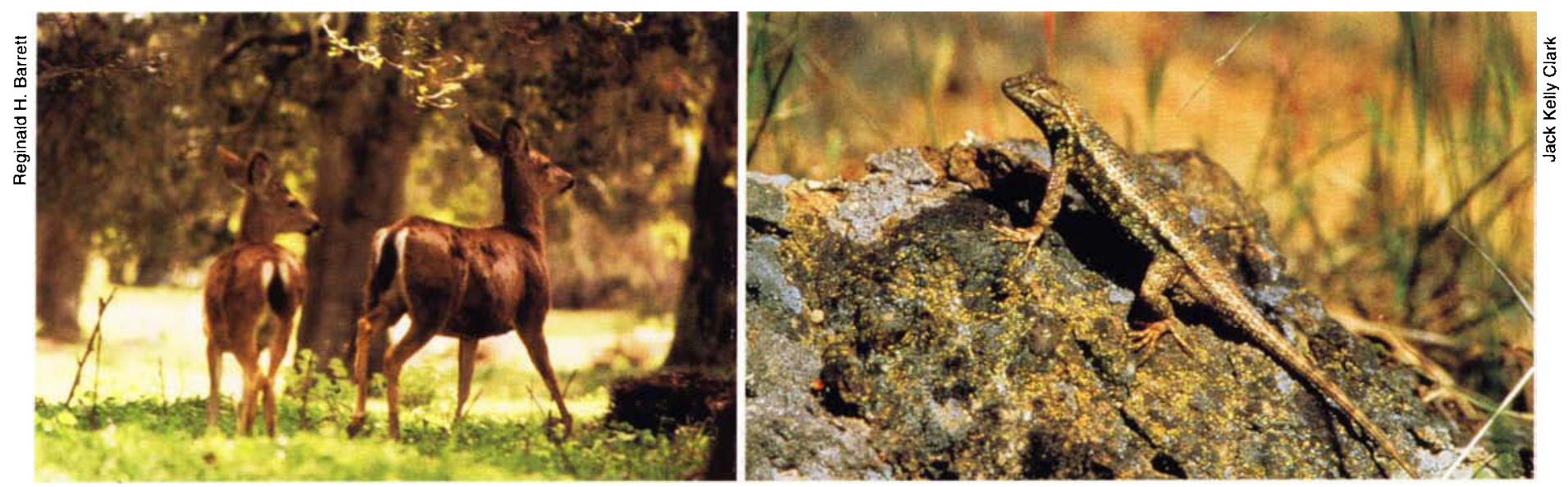

Scientists at HREC have undertaken important investigations of the relationships among wildlife, parasites and human disease. Columbian black-tailed deer, left, host at least 86 species of parasitic helminths, flies, ticks, mites and fleas,

\begin{abstract}
some of which carry infectious disease agents. When infected nymphs of the western black-legged tick attach to the western fence lizard, right, they imbibe proteins with the blood meal that invariably destroys the Lyme disease spirochete.
\end{abstract}

abundance or spread of infectious disease organisms. In Sweden, the observed expansion in the density and geographic range of the sheep tick ( $I x-$ odes ricinus) is believed to be due partly to the mild climate of the 1990 s (Lindgren et al. 2000). Because the sheep tick is the primary vector of Lyme disease spirochetes and tickborne encephalitis virus in northern Europe, it is likely that many wildlife populations as well as humans are encountering these pathogens for the first time.

\section{Long-term studies at Hopland}

Long-term studies of wildlife parasites or arthropod-borne zoonoses in natural areas like the HREC provide distinct advantages. For one, the natural transmission cycles of zoonotic disease agents or of nonzoonotic wildlife parasites can be clarified in a secure setting unencumbered by human intervention. This enables researchers to determine how macroparasites or $\mathrm{mi}$ crobial agents are maintained and distributed in nature. In the process, weak links in the chain of infection may be identified, which later can be exploited to develop and implement effective preventive or control strategies.

Wildlife parasites have been the subject of numerous studies at HREC since the 1950s. Research on Columbian black-tailed deer has yielded the most comprehensive database for macroparasites associated with a species of deer worldwide. This deer hosts 86 species of parasitic helm- inths, blood-sucking flies, eye-feeding flies, internal or external parasitic flies, ticks, mites and a flea. The guild of blood-sucking flies that feed on this deer includes vectors of three different parasitic nematodes, one of which causes severe dermatitis in sheep (Anderson 1991). Furthermore, adults of the western black-legged tick (I. pacificus), which is the primary vector of the Lyme disease spirochete (Borrelia burgdorferi) in the far-western United States, use deer as a principal source of their blood meals. Spirochetes are spiral-shaped bacteria, some of which can cause diseases in humans and other animals (such as syphilis, leptospirosis). Deer were also shown to be infected with an array of microbial organisms causing such human and other animal diseases as anaplasmosis, Colorado tick fever, ehrlichiosis, Lyme disease, Q-fever, rabies and tularemia.

The value of long-term studies of arthropod-borne zoonotic diseases at a research facility like HREC is exemplified by work conducted there on Q-fever from 1964 to 1967 (Enright et al. 1969; Enright, Longhurst et al. 1971; Enright, Behymer et al. 1971; Enright, Franti et al. 1971), Rocky Mountain spotted fever and other rickettsiae from 1974 to 1980 (Lane, Emmons et al. 1981; Lane, Philip et al. 1981; Philip et al. 1981, 1982) and on Lyme disease and other spirochetes from 1982 to the present (Burgdorfer et al. 1985; Lane et al. 1985; Brown and Lane 1992;
Tälleklint-Eisen and Lane 1999). During these multiyear investigations, scientists elucidated the vectorpathogen-host interrelationships for each of these bacterial agents to varying degrees, as well as the intimate association among sheep, wild mammals and birds in the complex ecology of Q-fever. Approximately 17 tick-borne microorganisms - including seven bacteria (which include the rickettsiae) and a virus - that infect or presumably infect humans, livestock or companion animals were detected in or isolated from ticks, vertebrates or both (table 1).

Evidence for one agent, a rickettsia (Ehrlichia sp.), is limited to the presence of elevated antibodies against it in blood from Columbian black-tailed deer (J.E. Dawson, personal communication). Since the agent has not been detected in or isolated from deer, other vertebrates or ticks at the HREC, nor has it been identified specifically, it is not included in table 1 . Nevertheless, two Ehrlichia spp. that are pathogenic for humans (E. chaffeensis and E. phagocytophila) have been detected in ticks from other locations in California. Three other partially characterized but unnamed spirochetes that may represent distinct Borrelia species have been isolated from ticks or small mammals, and five additional rickettsiae have been recovered from ticks (Lane, Philip et al. 1981; Philip et al. 1981, 1982; Postic et al. 1998).

Three of the characterized microbes are agents of emerging or potentially 


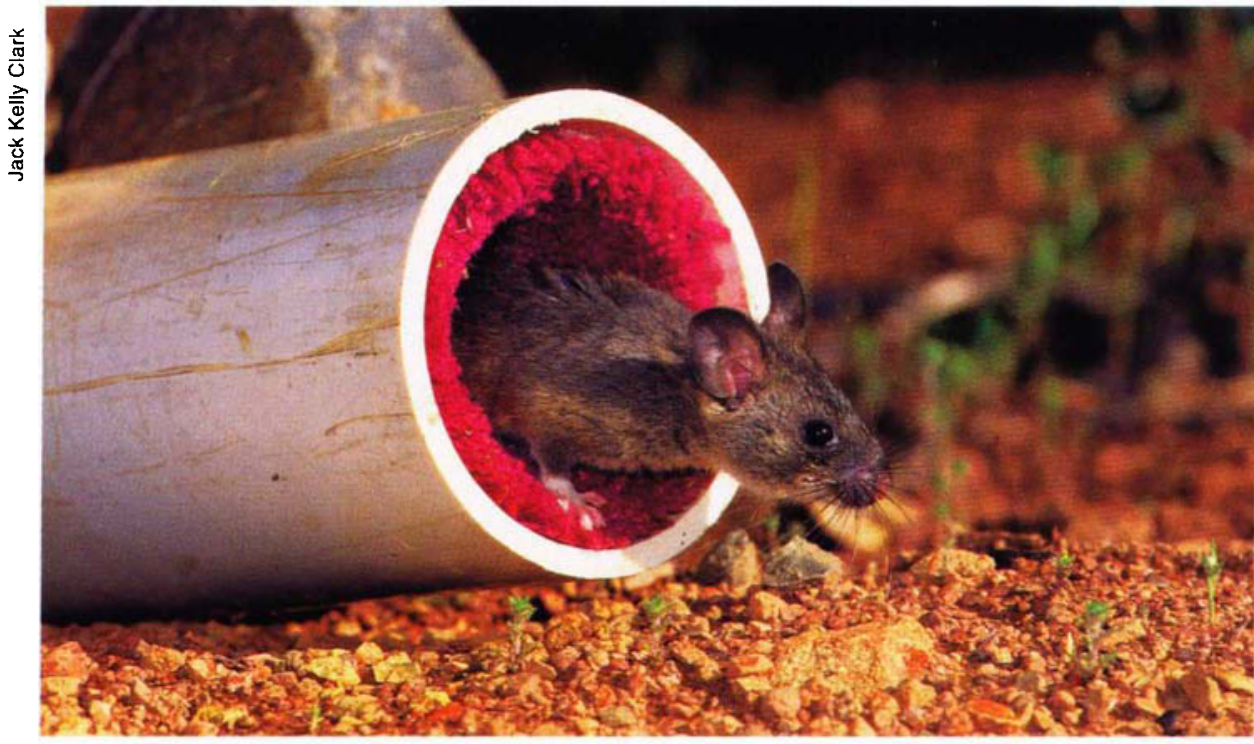

When wood rats travel through a permethrin-treated bait tube, their flea and tick populations are significantly reduced. Modifications of this treatment could help to reduce tick vectors of human pathogens on other types of wildlife.

emerging diseases: the Lyme disease spirochete (B. burgdorferi), the most significant emerging arthropod-borne disease in the Northern Hemisphere; the closely related and recently described spirochete $B$. bissettii, which has been incriminated as causing a Lyme disease-like illness in humans in Slovenia (Strle et al. 1997; Postic et al. 1998); and a little-known but significantly different variant of Colorado tick fever virus that occasionally may infect people in western California (Lane et al. 1982).

\section{Lyme disease, lizards and ticks}

Lyme disease is a potentially debilitating and sometimes chronic infection transmitted to humans and other animals by certain ticks. It typically begins with flulike symptoms, which often are accompanied by a slowly expanding reddish rash; if left untreated, serious arthritic, cardiac or neurologic problems can develop. In the western United States, more cases of Lyme disease are reported from California each year than from the other states combined. Since it was designated as a reportable disease in California in 1989, a total of 1,938 cases were reported through 1999 (Lane 2000). Roughly half of all California cases between 1990 and 1997 originated in six northwestern coastal counties (Humboldt, Lake, Marin, Mendocino, Sonoma, Trinity) (R. A. Murray, personal com- munication). This region, especially the Hopland and Ukiah areas in southern Mendocino County, is where intensive ecological and epidemiological investigations of the Lyme disease spirochete have been conducted since the early 1980 s.

The first isolate of the Lyme disease spirochete from western North America was obtained from an adult western black-legged tick collected at the HREC (Burgdorfer et al. 1985).

Subsequently, the natural maintenance cycle of the spirochete was found to differ markedly from that in the northeastern and upper midwestern United States (Brown and Lane 1992). Wood rats, kangaroo rats and deer mice function as reservoir hosts; the human-biting western black-legged tick and two nonhuman-biting Ixodes spp. ticks serve as vectors, and the spirochetes are more variable antigenically and genetically. Furthermore, factors that elevate the risk of human exposure to spirochete-infected ticks were identified, particularly cutting wood and being exposed to leaf-litter areas in mixed hardwood forests during the spring-summer activity period

Long-term studies have garnered important data on Q-fever, Rocky Mountain spotted fever, Lyme disease and other arthropod-borne zoonotic diseases. At the HREC, scientist Bob Lane removes fleas from a mouse. of western black-legged tick nymphs (Lane et al. 1992; Clover and Lane 1995; Tälleklint-Eisen and Lane 1999).

One of the more exciting discoveries was that the western fence lizard (Sceloporus occidentalis) is a highly incompetent host for the Lyme disease spirochete. This lizard, albeit a primary host of western black-legged tick immatures (larvae and nymphs) in many habitats, is a dead-end spirochetal host because it contains a spirochete-killing (borreliacidal) immune factor in its blood (Lane and Quistad 1998; Kuo et al. 2000); adult ticks do not feed on lizards. Consequently, spirochetes present in the midguts of nymphal ticks are destroyed during or soon after they ingest the lizard-blood meal (Lane and Quistad 1998). Eliminating spirochetes from western black-legged tick nymphs reduces the likelihood of Lyme disease transmission to humans and other animals by decreasing the prevalence of infection in the next life stage, the adult tick. This fact is believed to account for the pronounced disparity in infection prevalences between host-seeking nymphs (about $5 \%$ to $15 \%$ ) and adult ticks (usually $1 \%$ to $2 \%$ ) in northwestern California.

\section{Epidemiological evidence}

Since its first recognition in the northeastern United States during the

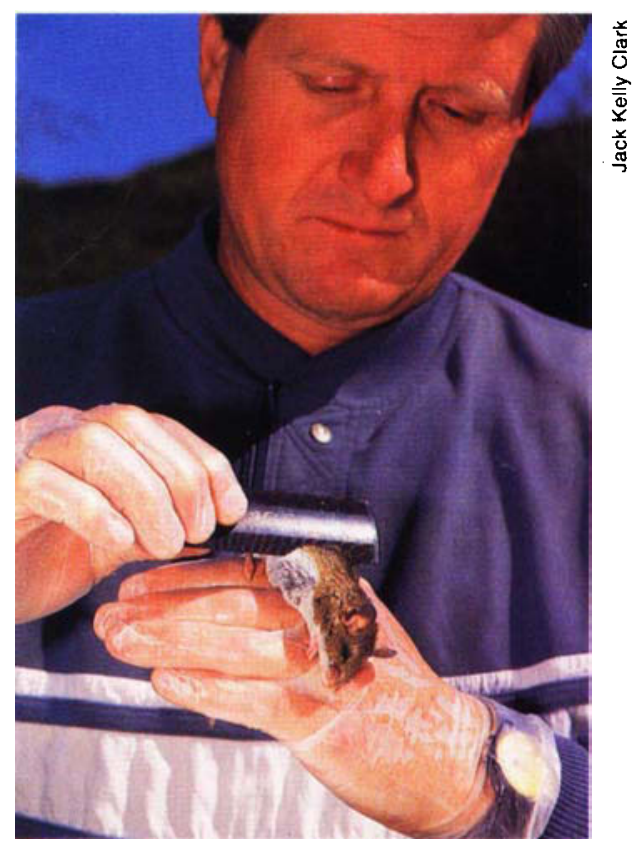




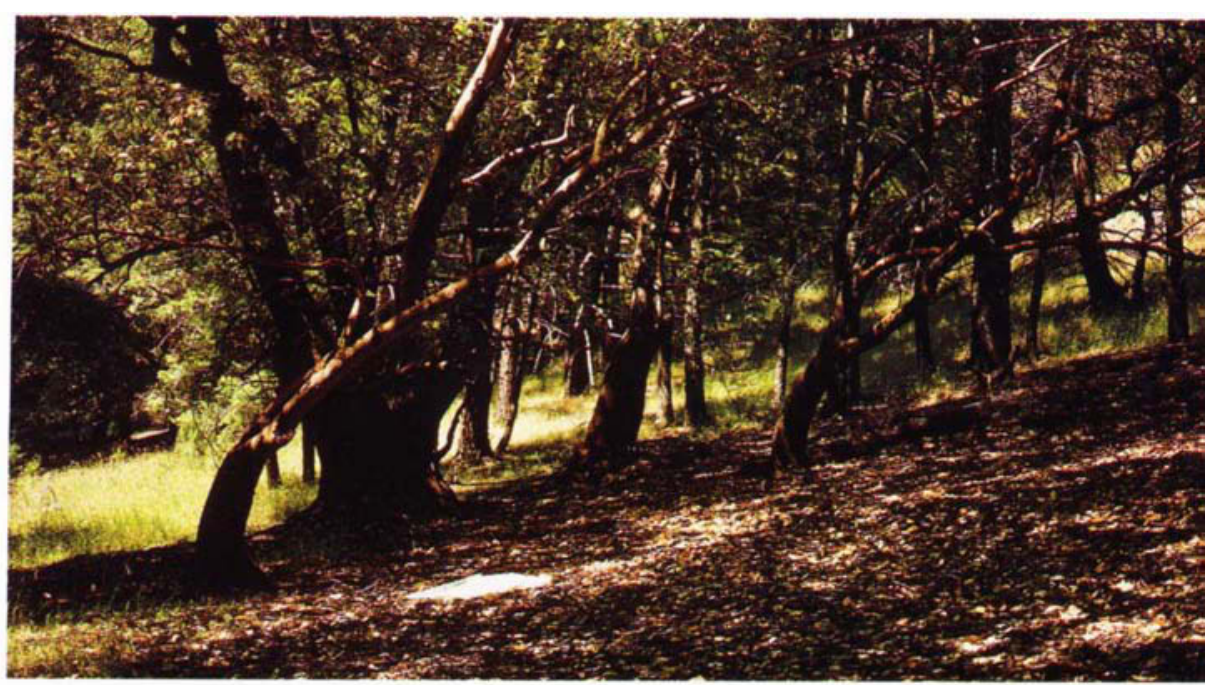

An epidemiological study of a Northern California rural community found that $24 \%$ of the population tested positive for Lyme disease. Frequent exposure to leaf-litter areas in hardwood forests may be linked to these high infection rates. The white cloth is dragged over the litter surface with a wooden handle to collect western black-legged tick nymphs; tick larvae and nymphs are found in leaf-litter areas much more frequently than the adults.

mid-1970s, Lyme disease has become a well-publicized and -monitored problem in that region and the upper Midwest. However, in the mid-to-late 1980s, Lyme disease was still thought to be a rare disease in the far-western United States that occurred episodically among hikers and other outdoor enthusiasts. In fact, some California physicians considered it a medical curiosity or even denied its existence. The low infection prevalence detected consistently in adult ticks during the initial tick/spirochete surveys in Northern California and southern Oregon reinforced this misconception (Burgdorfer et al. 1985; Bissett and Hill 1987).

Then in the late 1980s, scientists launched an investigation of a small rural community (population of approximately 150) in the Ukiah area of southern Mendocino County not far from the HREC. Blood tests revealed that $\geq 24 \%$ of the residents tested positive for Lyme disease, a cumulative frequency similar to those reported in some highly endemic areas of the northeastern United States (Lane et al. 1992). Epidemiologically, this presented a seemingly unsolvable conundrum: How could such a large proportion of the study subjects in this high-risk community have Lyme disease if only $1.3 \%$ of 684 adults of the western black-legged tick surveyed areawide were infected with the Lyme disease spirochete (Lane et al. 1992)?
The answer followed soon thereafter when leaf-litter areas in mixed hardwood forests were discovered to be the principal habitats of western black-legged tick nymphs in Mendocino County (Clover and Lane 1995; Tälleklint-Eisen and Lane 1999). Moreover, spirochetal infection prevalences in western black-legged tick nymphs averaged $13.6 \%$ and $12.4 \%$ in those studies, one of which was carried out in the high-risk community (Tälleklint-Eisen and Lane 1999). These nymphal infection prevalences are comparable to those in some highly endemic areas of the northeastern United States. The enigmatically high $\geq 24 \%$ seropositivity rate detected among residents of the highrisk community now could be reinterpreted in terms of probable human exposure to abundantly infected nymphal ticks inhabiting leaf-litter areas surrounding the home. Subsequently, the low infection prevalences in adult ticks there and elsewhere in Northern California became understandable after the role of lizards in "cleansing" infected nymphal ticks of their spirochetal burdens had been established (Lane and Quistad 1998).

\section{Risk assessment, research needs}

These discoveries prompted a longterm risk-assessment study (from 1997 to 2001) at the high-risk community and, as a comparison area, the HREC, in an effort to identify specific factors that might elevate human exposure to Lyme disease spirochetes. Data gathered to date have revealed extraordinary spatial and temporal variation in the prevalence and density of infected nymphs within and between both areas. For example, there was a 10 -fold variation in the prevalence $3.9 \%$ to $41.3 \%$ ) and a 76 -fold variation in the density of infected nymphs between individual properties at the high-risk community in 1998 (Tälleklint-Eisen and Lane 1999).

Ongoing and planned studies include an expansion of the nymphaltick surveys to incorporate sites representative of different major habitats and climatic zones throughout Mendocino County, in collaboration with the Vector-Borne Disease Section of the California Department of Health Services. These surveys will assess numerous factors as possible determinants of nymphal density and the abundance of infected nymphs in leaf-litter areas, and eventually will use a combination of remote sensing and ecological studies to model Lyme disease risk countywide. In addition to current members of UC Berkeley tick-research programs, other participants will include colleagues at the HREC and the University of Illinois at Urbana.

The ultimate goal of this research is to use the basic parasitologic knowledge gathered over recent decades at the HREC to prevent and control tickborne diseases in humans. Three hosttargeted methods for controlling ticks infesting the dusky-footed wood rat have been evaluated in brushlands at the HREC. One of them, a modification of the liquid permethrin-treated bait tube developed earlier by CDC, was remarkably effective for reducing populations of both ticks and fleas on wood rats (Lane et al. 1998). Because three of the four ticks infesting wood rats in the study area can transmit one or more bacterial zoonotic agents, this approach offers considerable promise as a tool in our arsenal for reducing the tick vectors of human pathogens in rural and semirural settings in the western United States. 
Finally, a recently updated educational report written mainly for the lay person provides useful information on the clinical manifestations of Lyme disease, current knowledge about the life history and habitat associations of the western black-legged tick, behavioral and environmental factors that may heighten exposure to vector ticks, and preventive measures for minimizing tick attachments (Lane 2000).

\section{R.S. Lane is Professor and J.R. Anderson} is Professor Emeritus, Division of Insect Biology, UC Berkeley. We thank the many staff members of the HREC (too numerous to mention) who facilitated the parasitologic research described here by contributing their time, expertise and labor. Special thanks to former and current superintendents Al Murphy and Bob Timm, former ranch foreman Fran Lile, and former and current staff biologists Guy Connolly and Bob Keiffer. Jackie Dawson of the CDC is gratefully acknowledged for permission to cite unpublished data about the presence of ehrlichial antibodies in deer. We also thank our innumerable co-workers who contributed invaluably to the body of research summarized here. The ongoing tickborne disease investigations of R.S. Lane and members of his program are funded in part by a grant from the National Institutes of Health (AI22501), a cooperative agreement from the $\mathrm{CDC}$ (U50) CCU906594), and the UC Agricultural Experiment Station and the Cooperative State Research Service, U.S. Department of Agriculture under project \#6305-AH.

\section{References}

Anderson JR. 1991. Arthropod parasites of deer at the UC Hopland Field Station. In: Schmidt RH, Timm RM, Tinnin PJ (compilers). Columbian Black-tailed Deer Workshop. Hopland Field Sta Pub 102. p 171-4.

Baker NF, Longhurst WM, Douglas JR. 1957. Experimental transmission of gastrointestinal nematodes between domestic sheep and Columbian black-tailed deer. In: Trans 22nd N Am Wildl Conf. p 160-8.

Baker NF, Longhurst WM, Torell DT, et al. 1954. Preliminary studies of parasitism in sheep on rangelands. Am J Vet Res 15:356-60.

Bissett ML, Hill W. 1987. Characterization of Borrelia burgdorferi strains isolated from Ixodes pacificus ticks in California. J Clin Microbiol 25:2296-301.
Brown RN, Lane RS. 1992. Lyme disease in California: A novel enzootic transmission cycle of Borrelia burgdorferi. Science 256:1439-42.

Burgdorfer W, Lane RS, Barbour AG, et al. 1985. The western black-legged tick, Ixodes pacificus: A vector of Borrelia burgdorferi. Am J Trop Med Hyg 34:925-30

[CDC] Centers for Disease Control and Prevention. 1994. Addressing emerging infectious disease threats: A prevention strategy for the United States (executive summary). MMWR 43 (No RR-5):1-18.

CDC. 1999. Recommendations for the use of Lyme disease vaccine: Recommendations of the Advisory Committee on Immunization Practices. MMWR (Suppl) 48 (No RR-7): 1-25.

Clover JR, Lane RS. 1995. Evidence implicating nymphal Ixodes pacificus (Acari: Ixodidae) in the epidemiology of Lyme disease in California. Am J Trop Med Hyg 53:237-40.

Daszak $P$, Cunningham AA, Hyatt AD.

2000. Emerging infectious diseases of wildlife - threats to biodiversity and human health.

Science 287:443-9.

Enright JB, Behymer DE, Franti CE, et al. 1971. The behavior of $Q$ fever rickettsiae isolated from wild animals in northern California. $J$ Wildl Dis 7:83-90.

Enright JB, Franti CE, Behymer DE, et al 1971. Coxiella burneti in a wildlife-livestock environment: Distribution of $Q$ fever in wild mammals. Am J Epidemiol 94:79-90.

Enright JB, Longhurst $\mathrm{W}$, Franti $\mathrm{CE}$, et al. 1969. Some observations on domestic sheep and wildlife relationships in Q-fever. Proc Annu Conf Bull Wildl Dis Assoc 5:276-83.

Enright JB, Longhurst WM, Wright ME, et al. 1971. Q-fever antibodies in birds. J Wildl Dis 7:14-21.

Ferber D. 2000. Human diseases threaten great apes. Science 289:1277-8.

Gratz NG. 1999. Emerging and resurging vector-borne diseases. Annu Rev Entomol 44:51-75.

Gubler DJ. 1998. Resurgent vector-borne diseases as a global health problem. Emerg Infect Dis 4:442-50.

Howarth JA, Hokama Y. 1973. Tick transmission of anaplasmosis under laboratory conditions. In: Proc 6th Natl Anaplasmosis Conf. p 117-20.

Howarth JA, Roby TO. 1973. Transmission of anaplasmosis by field collections of Dermacentor occidentalis Marx (Acarina: Ixodidae). In: Proc 76th Annu Mtg US Anim Health Assoc. p 98-102.

Johnson RC, Burgdorfer W, Lane RS, et al. 1987. Borrelia coriaceae sp. nov.: Putative agent of epizootic bovine abortion. Int J Syst Bacteriol 37:72-4.

Kuo MM, Lane RS, Giclas PC. 2000. A comparative study of mammalian and reptilian alternative pathway of complement-mediated killing of the Lyme disease spirochete (Borrelia burgdorferi). J Parasitol 86:1223-8.

Lane RS. In press. Arthropod-borne zoonoses. In: Resh VH, Cardé R (eds.). Encyclopedia of Insects. San Diego: Academic Press.

Lane RS. 2000. Lyme disease in California. Pest Notes. UC DANR Pub 7485. $3 \mathrm{p}$

Lane RS, Burgdorfer W, Hayes SF, et al.
1985. Isolation of a spirochete from the soft tick, Ornithodoros coriaceus: A possible agent of epizootic bovine abortion. Science 230:85-7.

Lane RS, Casher LE, Peavey CA, et al. 1998. Modified bait tube controls diseasecarrying ticks and fleas. Cal Ag 52(2):43-7.

Lane RS, Emmons RW. 1977. Ecologica and epidemiological studies of tularemia in California. Calif Vector Views 24:39-49.

Lane RS, Emmons RW, Devlin V, et al. 1982. Survey for evidence of Colorado tick fever virus outside of the known endemic area in California. Am J Trop Med Hyg 31:837-43.

Lane RS, Emmons RW, Dondero DV, et al. 1981. Ecology of tick-borne agents in California. I. Spotted fever group rickettsiae. Am J Trop Med Hyg 30:239-52.

Lane RS, Manweiler SA, Stubbs HA, et al. 1992. Risk factors for Lyme disease in a small rural community in northern California. Am J Epidemiol 136:1358-68.

Lane RS, Philip RN, Casper EA. 1981. Ecology of tick-borne agents in California. II. Further observations on rickettsiae. In: Burgdorfer W, Anacker RL (eds.). Rickettsiae and Rickettsial Diseases. New York: Academic Press. p 575-84.

Lane RS, Quistad GB. 1998. Borreliacidal factor in the blood of the western fence lizard (Sceloporus occidentalis). J Parasitol 84:29-34

Lindgren E, Tälleklint L, Polfeldt T. 2000. Impact of climatic change on the northern latitude limit and population density of the disease-transmitting European tick Ixodes ricinus. Environ Health Perspect 108:119-23.

Longhurst WM, Douglas JR. 1953. Parasite interrelationships of domestic sheep and Columbian black-tailed deer. In: Trans 18th N Am Wildl Conf. p 168-88.

Morgan UM. 2000. Detection and characterisation of parasites causing emerging zoonoses. Int J Parasitol 30:1407-21.

Philip RN, Casper EA, Anacker RL, et al. 1982. Identification of an isolate of $V$ Rickettsia canada from California. Am J Trop Med Hyg 31:1216-21.

Philip RN, Lane RS, Casper EA. 1981. Serotypes of tick-borne spotted fever group rickettsiae from western California. Am J Trop Med Hyg 30:722-7.

Postic D, Ras NM, Lane RS, et al. 1998. Expanded diversity among Californian Borrelia isolates and description of Borrelia bissettii sp. nov. (formerly Borrelia group DN127). J Clin Microbiol 36:3497-504.

Strle F, Picken RN, Cheng Y, et al. 1997. Clinical findings for patients with Lyme borreliosis caused by Borrelia burgdorferi sensu lato with genotypic and phenotypic similarities to strain 25015. Clin Infect Dis 25:273-80.

Tälleklint-Eisen L, Lane RS. 1999. Variation in the density of questing /xodes pacificus (Acari: Ixodidae) nymphs infected with Borrelia burgdorferi at different spatial scales in California. J Parasitol 85:824-31.

Taylor LH, Woolhouse MEJ. 2000. Zoonoses and the risk of disease emergence. Int Conf Emerg Infect Dis Atlanta (Program \& Abstracts Book, Late Breaker Poster Session, Board 122. p 14). 